\title{
Agile characteristics of employees and their role in risk management
}

\author{
Andrzej Olak ${ }^{1 *}$, Waldemar Karwowski ${ }^{2}$
}

1* Assistant professor, Institute of Economics and Management, Bronislaw Markiewicz State Higher School of

Technology and Economics in Jaroslaw, Poland; ${ }^{2}$ Professor, Faculty of Management, University of Information

Technology and Management in Rzeszow, Poland.

Email: ${ }^{1 *}$ andrzej.olak@pwste.edu.pl, ${ }^{2}$ wkarwowski@wsiz.edu.pl

\section{Keywords}

Agile Management, Agile Organization,

Employee Agility, Risk Management.

\section{Article History}

Received on $23^{\text {rd }}$ October 2021

Accepted on $30^{\text {th }}$ October 2021

Published on $3^{\text {rd }}$ November 2021

\section{Cite this article}

Olak, A., \& Karwowski, W. (2021). Agile

characteristics of employees and their role in risk

management. Humanities \& Social Sciences

Reviews, 9(6), 01-10.

https://doi.org/10.18510/hssr.2021.961

\section{Copyright @Author}

Publishing License

This work is licensed under a Creative Commons Attribution-Share Alike 4.0 International License

\begin{abstract}
Purpose of the study: In order to survive in the face of contemporary risks, organizations are forced to initiate the evolution of employee behavior towards developing agile traits. The article, based on the concept of agility and classification of agile employee characteristics defined in the literature, aims to present the theoretical model of the behavior of agile employees in the face of organizational risk.
\end{abstract}

Methodology: The model presented in the article was developed on the basis of a critical analysis of the literature in the field of agile management and risk management.

Main Findings: One of the possible reactions of modern enterprises to the emergence of organizational risk is promoting employee agility. An agile employee is able to effectively anticipate problems related to the occurrence of risk, has the ability to solve problems related to the occurrence of risk. Such an employee is able to implement innovative ideas and perform his duties effectively in stressful conditions, as well as propose new procedures or processes for his area of work.

Applications of this study: The presented model of agile behavior of employees in the face of organizational risk is of a utilitarian nature and can be implemented in the organizational culture of various entities, including small and medium-sized enterprises.

Novelty/Originality of this Study: Research originality: The article allows for a better understanding of the need to develop agile traits in employees and the possibility of using them to eliminate or minimize risks. The article may be an inspiration for further research on the role of employee agility in the enterprise. 


\title{
Zwinne cechy pracowników i ich rola w zarządzaniu ryzykiem
}

\author{
Andrzej Olak $^{{ }^{*}}$, Waldemar Karwowski ${ }^{2}$
}

1*Adiunkt, Instytut Ekonomii i Zarządzania, Państwowa Wyższa Szkoła Techniczno-Ekonomiczna im. ks. Bronisława Markiewicza w Jarosławiu, Polska; ${ }^{2}$ Profesor, Kolegium Zarządzania, Wyższa Szkoła Informatyki i Zarządzania z siedzibą w Rzeszowie, Polska.

Email: ${ }^{1 *}$ andrzej.olak@pwste.edu.pl, ${ }^{2}$ wkarwowski@wsiz.edu.pl

\author{
Slowa kluczowe \\ Zwinne Zarządzanie, Zwinna Organizacja, Zwinność \\ Pracownicza, Zarządzanie Ryzykiem.
}

Historia artykułu

Otrzymano 23 październik 2021

Przyjęta 30 październik 2021

Opublikowane 3 Listopad 2021

\section{Cite this article}

Olak, A., \& Karwowski, W. (2021). Agile

characteristics of employees and their role in risk

management. Humanities \& Social Sciences Reviews,

9(6), 01-10. https://doi.org/10.18510/hssr.2021.961

\section{Copyright @Author}

Publishing License

This work is licensed under a Creative Commons Attribution-Share Alike 4.0 International License

\section{Streszczenie}

Cel opracowania: Organizacje, aby przetrwać w obliczu współczesnych ryzyk, zmuszone są do zainicjowania ewolucji zachowań pracowników w kierunku wykształcenia cech zwinnych. Artykuł, bazując na zdefiniowanych w literaturze: pojęciu zwinności i klasyfikacji pracowniczych cech zwinnych, zmierza do prezentacji teoretycznego modelu zachowania zwinnych pracowników w obliczu pojawienia się ryzyka organizacyjnego.

Metodologia: Prezentowany w artykule model wypracowany został na podstawie krytycznej analizy literatury z zakresu zwinnego zarządzania $\mathrm{i}$ zarządzania ryzykiem.

Główne wnioski: Jedną $\mathrm{z}$ możliwych reakcji współczesnych przedsiębiorstw na pojawienie się ryzyka organizacyjnego jest promowanie zwinności pracowniczej. Zwinny pracownik potrafi skutecznie przewidywać problemy występujące $\mathrm{W}$ związku $\mathrm{Z}$ pojawieniem się ryzyka, posiada umiejętność rozwiązywania problemów związanych $\mathrm{z}$ wystąpieniem ryzyka. Taki pracownik potrafi wdrożyć innowacyjne pomysły i efektywnie wykonywać swe obowiązki w stresujących warunkach, a także zaproponować nowe procedury lub procesy dla swojego obszaru pracy.

Praktyczne zastosowanie badania: Przedstawiony model zachowań zwinnych pracowników w obliczu pojawienia się ryzyka organizacyjnego ma charakter utylitarny i może zostać wdrożony w kulturze organizacyjnej różnych podmiotów, w tym małych i średnich przedsiębiorstw.

Oryginalność opracowania: Artykuł pozwala na lepsze zrozumienie potrzeby wykształcenia u pracowników cech zwinnych i możliwości wykorzystania ich w celu eliminacji lub minimalizowania ryzyk. Artykuł może być inspiracją do dalszych badań nad rolą zwinności pracowniczej w przedsiębiorstwie.

\section{WPROWADZENIE}

Szybkie tempo wprowadzania innowacji, fragmentacja rynków, wzrastające oczekiwania klientów wobec produktów i usług oraz gwałtowny rozwój technologiczny, prowadzą do burzliwych zmian w środowisku biznesowym. Niepewność otoczenia, wzrost znaczenia więzi współzależności pomiędzy podmiotami gospodarczymi, pogłębiająca się globalizacja procesów gospodarczych, sytuacja ogólnogospodarcza kraju i stosunków międzynarodowych, pojawienie się procesów integracji w warunkach niestabilności rynków należą do źródeł, które mogą implikować występowanie ryzyka organizacyjnego. Organizacje, aby przetrwać w obliczu takiego ryzyka, zmuszone są do zainicjowania ewolucji zachowań pracowników w kierunku wykształcenia cech zwinnych, które wykształciły się jako odpowiedź na pojawiające się ryzyko organizacyjne. Celem artykułu jest przedstawienie cech zwinnych pracowników w obliczu pojawienia się ryzyka. Stwierdzono, iż pojawiające się różne rodzaje ryzyka komplikują kształcenie postaw zwinnych pracowników. Przedstawiono utylitarny model zachowań zwinnych w obliczu pojawienia się ryzyka organizacyjnego.

\section{ZWINNOŚĆ PRACOWNICZA W UJECIU TEORETYCZNYM}

Współczesnym przedsiębiorstwom przyszło funkcjonować w turbulentnym i często nieprzewidywalnym otoczeniu rynkowym, które wymusza poszukiwanie orientacji strategicznej, pozwalającej na wykorzystanie nadarzających się okazji rynkowych oraz zmierzenie się z rosnącymi wymaganiami klientów. Tak przedstawione cele może osiągnąć tylko organizacja, która nosi znamiona zwinnej. W literaturze naukowej znajduje się wiele definicji pojęć „,zwinności” i „zwinnej organizacji”. Pojęcia te rozumie się głównie jako głównie jako zdolność do błyskawicznej reakcji i umiejętność przystosowania się do nowych warunków w odpowiedzi na ciągłe, zaskakujące i nieprzewidywalne zmiany środowisk rynków konkurencyjnych. W Tabeli 1. dokonano przeglądu definicyjnego pojęcia „zwinność”. Analiza ta pozwala stwierdzić, że zjawisko zwinności należy definiować w kategorii wykształcenia przez organizację zdolności do szybkiej reakcji na zmiany zachodzące w otoczeniu rynkowym, a także zdolność do proaktywnych działań i wykorzystania nowych możliwości. 
Tabela 1: Przegląd definicyjny zwinności organizacyjnej

\begin{tabular}{|c|c|}
\hline Autor & Definicja zwinności \\
\hline$\underline{\text { Kidd (1994) }}$ & $\begin{array}{l}\text { Szybka reakcja dzięki elastycznemu dostosowaniu przez zwinne } \\
\text { przedsiębiorstwo każdego ze swoich komponentów, takich jak sformułowane } \\
\text { cele organizacji, pracownicy oraz technologia, do nieoczekiwanych zmian. }\end{array}$ \\
\hline Sanchez, Nagi (2001) & $\begin{array}{l}\text { Strategiczna umiejętność organizacji do błyskawicznej adaptacji oraz } \\
\text { szybkiego przystosowania się to nieprzewidzianych i turbulentnych zmian na } \\
\text { rynku. }\end{array}$ \\
\hline Goldman i in. (1995) & $\begin{array}{l}\text { Pełna asymilacja wszystkich elastycznych technologii produkcyjnych z } \\
\text { metodami lean production (produkcji odchudzonej), doświadczeniem, } \\
\text { zdobytym podczas kompleksowego zarządzania jakością (TQM) oraz } \\
\text { produkcji w systemie "just-in-time" (JIT). }\end{array}$ \\
\hline Zhang, Sharifi (2000) & $\begin{array}{l}\text { Doskonałe radzenie sobie organizacji ze zmianami dzięki wykształceniu } \\
\text { umiejętności przetrwania w otoczeniu rynkowym pełnym zagrożeń. }\end{array}$ \\
\hline$\underline{\text { Rigby }(2000)}$ & $\begin{array}{l}\text { Zdolność do przetrwania w zmiennych warunkach rynkowych poprzez } \\
\text { wytworzeniu prawidłowej reakcji na pojawiające się zmiany w otoczeniu } \\
\text { rynkowym. }\end{array}$ \\
\hline Narasimhan i in. (2006) & $\begin{array}{l}\text { Umiejętność przeprowadzenia wydajnej zmiany poziomu operacyjnego, } \\
\text { rozumianej jako reakcja na wzrastające wciąż wymagania klientów. }\end{array}$ \\
\hline Gunasekaran (1998) & $\begin{array}{l}\text { Zdolność do przetrwania, jak i radzenia sobie w konkurencyjnym, } \\
\text { turbulentnym, zmiennym i nieprzewidywalnym otoczeniu rynkowym, } \\
\text { pełnym zmian, wymagających błyskawicznej reakcji na bodźce rynkowe. } \\
\text { Umiejętność sprostania wzrastającym wymaganiom klientów na } \\
\text { ewoluującym i zmieniającym się rynku, podjęcie działań, umożliwiających } \\
\text { utrzymanie przewagi konkurencyjnej. }\end{array}$ \\
\hline Meredith, Francis (2000) & $\begin{array}{l}\text { Uzyskanie konkurencyjnej pozycji na rynku poprzez inteligentne i } \\
\text { błyskawiczne wykorzystanie nadarzających się okazji w otoczeniu } \\
\text { biznesowym. }\end{array}$ \\
\hline Storey i in. (2005) & $\begin{array}{l}\text { Konglomerat powiązanych ze sobą zmian w obszarze produkcji, wzornictwa, } \\
\text { marketingu i organizacji. }\end{array}$ \\
\hline Bessant $\mathrm{i}$ in. (1999) & $\begin{array}{l}\text { Dynamiczna umiejętność zdobywania przewagi konkurencyjnej dzięki } \\
\text { błyskawicznemu, szybkiemu, inteligentnemu wyznaczeniu szans rynkowych } \\
\text { i reakcji na zagrożenia. }\end{array}$ \\
\hline D'Aveni (1994) & $\begin{array}{l}\text { Wykorzystywanie pojawiających się okazji i traktowanie ich jako bodźców } \\
\text { do osiągnięcia innowacyjnych rozwiązan rynkowych, umiejętne } \\
\text { wykorzystanie ich w procesie konkurowania na rynku, sprawna alokacja } \\
\text { wiązanki zasobów, relacji rynkowych i wiedzy. }\end{array}$ \\
\hline Hormozi (1999) & „Wpadanie w objęcie zmiany” i błyskawiczne adoptowanie się do niej. \\
\hline Liao, Subramony (2008) & $\begin{array}{l}\text { Umiejętność funkcjonowania ,zawsze blisko rynku i klienta finalnego”, } \\
\text { wytworzenie strategicznego przywództwa, wypracowanie elastycznego } \\
\text { potencjału operacyjnego, sprawne kooperowanie z dostawcami, umiejętność } \\
\text { korzystania z dobrodziejstw informatycznych systemów, wspierających } \\
\text { zarządzanie. }\end{array}$ \\
\hline Sherehiy i in. (2007) & $\begin{array}{lccccc}\text { Unikalna wiedza i umiejętności pracowników, } & \text { pozwalające } & \text { na } \\
\text { przystosowanie się do zmiennych warunków rynkowych. } & & \\
\end{array}$ \\
\hline Trzcieliński (2007) & $\begin{array}{l}\text { Szybka reakcja na pojawiające się okazje i zagrożenia występujące w } \\
\text { otoczeniu biznesowym. Umiejętność wykorzystania szans rynkowych, } \\
\text { osiągnięcie wyznaczonych celów i pożądanych skutków. }\end{array}$ \\
\hline
\end{tabular}

Źródło: Opracowanie własne

\section{ZWINNE CECHY PRACOWNIKÓW I ICH CHARAKTERYSTYKA}

W przeszłości głoszono teorie, według której zwinność, elastyczność i szybkość reakcji można uwarunkowana była zastosowaniem zaawansowanych technologii, do których należało komputerowo zintegrowane wytwarzanie (CIM) (Youndt i in., 1996, s. 836-866). Nowsze wyniki badań empirycznych jednoznacznie wskazują, iż elastyczność produkcji uzależniona jest głównie od pracowników, a nie, jak wcześniej uważano, od technologii (Upton, 1995, s. 205-224).

Powszechnie uważa się, że zwinność pracownicza może zagwarantować organizacjom imponujący wachlarz korzyści, jak ulepszenie jakości produktów i usług, szybsze zdobywanie wiedzy przez organizacje, lepszą kulturę organizacyjną, oraz gospodarkę firmy, a także efektywniejszą obsługę klienta (Herzenberg i in., 1998, s. 4-21; Hopp i in., 2004, s. 8398). Wykształcenie zwinnych cech pracowników pozostaje warunkiem osiągnięcia zwinności organizacyjnej (Plonka, 1997, s. 11-20; Sajdak, 2013, s. 60). 


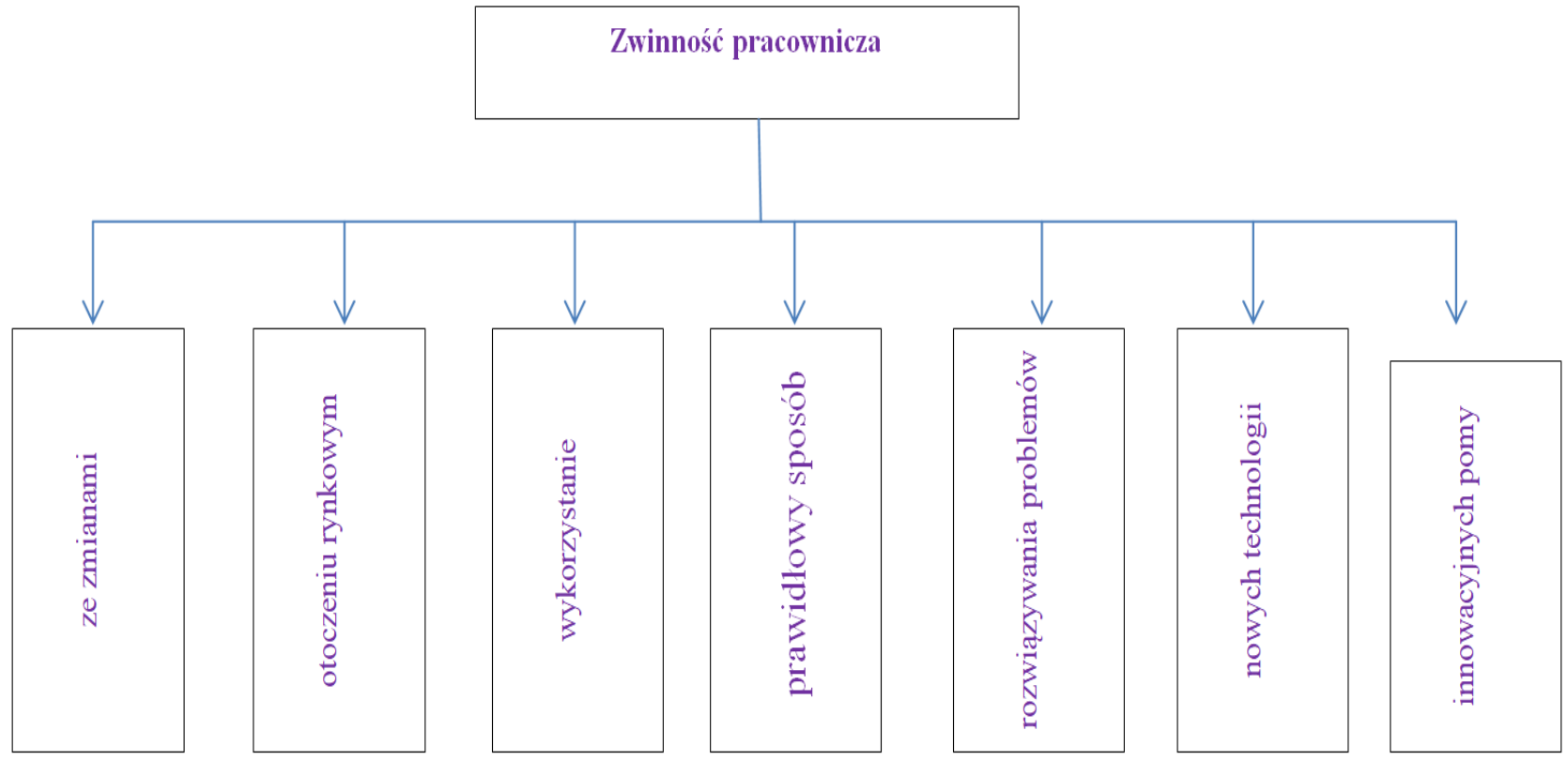

Rysunek 1: Istota zwinności pracowniczej

Źródło: Opracowanie własne

Zwinność pracowniczą można rozpatrywać jako umiejętność szybkiej odpowiedzi na zmiany dokonujące się w wewnętrznym i zewnętrznym środowisku rynkowym, jak również umiejętność prawidłowego wykorzystywania tych zmian i stwarzanie nowych możliwości powstałych w związku z ich wystąpieniem. Breu i inni sprecyzowali wskaźniki zwinności pracowników, takie jak: szybkość reakcji na zmiany zewnętrzne, szybkość rozwoju własnych umiejętności, ocena posiadanych umiejętności, szybkość adaptacji do nowych warunków pracy, szybkość wprowadzania zmian, szybkość dostępu do informacji, wykorzystanie technologii mobilnych, niezależność miejsca pracy, mobilny dostęp do informacji, praca w wirtualnych zespołach, dzielenie się wiedzą, technologie stawiające na współpracę (Breu i in., 2002, s. 84).

Plonka (1997, ss. 11-20) zauważa, że zwinność pracowniczą można rozpatrywać jako: 1) umiejętność dostosowania się do wymogów nowego sprzętu, 2) umiejętność dostosowania się do pracy z zespołem praktykującym inne metody pracy, 3) umiejętność jednoczesnej pracy nad kilkoma projektami, 4) dostosowanie się do nowych procedur pracy, oraz 5) utrzymywanie dobrych relacji z osobami z różnych działów. Turbulentne warunki rynkowe, zachodzące w otoczeniu biznesowym oraz wymogi pracy implikują wyksztalcenie się zachowań zwinnych (Bełz, Barbasz, 2014, s. 61). Do takich warunków należą m.in.: 1) zdolność błyskawicznego dostrzegania okazji rynkowych, 2) szybkie rozpoznanie zagrożeń płynących z otoczenia, 3) sprawna realizacja zadań i bieżące sterowanie realizacją tych zadań, 4) umiejętność kategoryzowania sytuacji w kontekście szans i zagrożeń, 5) sprawna kompilacja „wizjonerstwa z zarządzaniem operacyjnym“, oznaczająca zdolność do szerzenia idei i osadzenia ich w działaniach organizacji, 6) prawidłowa ocena adekwatności zasobów i możliwości ich pozyskiwania z otoczenia.

Sharifi i Zhang (1999, s. 7-22) klasyfikują zwinne cechy według czterech kategorii (por. rys. 2). Doz i Kosonen (2008) wśród cech zwinnych wyróżniają ponadto: 1) zdolność do rekonfiguracji systemów biznesowych, 2) całkowite zaangażowanie zespołu interpretowane w kategorii umiejętności zespołów na wysokich szczeblach zarządzania, 3) sprawne podejmowanie ważnych dla organizacji decyzji, oraz 4) wrażliwość strategiczną, rozumianą jako ostrość percepcji świadomości i atencji.

Postawienie pracownika przed koniecznością dostosowania się do zmiennych warunków rynkowych i organizacyjnych wymusiło na nim ciągłą ewolucję zachowania, przez co stał się on wykwalifikowany pod kątem stosowania rozwiązań IT, potrafiący współdziałać w zespole, wielofunkcyjny i posługujący się wieloma językami, obdarzony wiedzą jak negocjować oraz jak stosować zaawansowane strategie produkcyjne i technologie (Gunasekaran, 1999, s. 180-187). Zatrudnienie zwinnego pracownika przynosi przedsiębiorstwu wiele korzyści, takich jak poprawa jakości produktów i usług, przyspieszenie zdolności zdobywania wiedzy przez przedsiębiorstwo, efektywniejsza obsługa klienta, lepsza kultura organizacyjna i gospodarka firmy (Herzenberg i in., 1998, s. 4-21; Van Oyen i in., 2004, s. 83-98).

\section{RYZYKO W ORGANIZACJI}

W świetle teorii podejmowania decyzji pojęcie ryzyka wyznacza taką sytuację decyzyjną, w której z jednej strony występuje niepewność, dotycząca przyszłych zdarzeń oraz kształtowania się określonych sytuacji, natomiast z drugiej strony pracownik podejmujący decyzję dysponuje subiektywnymi informacjami na temat rozkładu prawdopodobieństwa dotyczącego kształtowania się sytuacji w przyszłości (Chrapko, 2010, s. 215-266). 


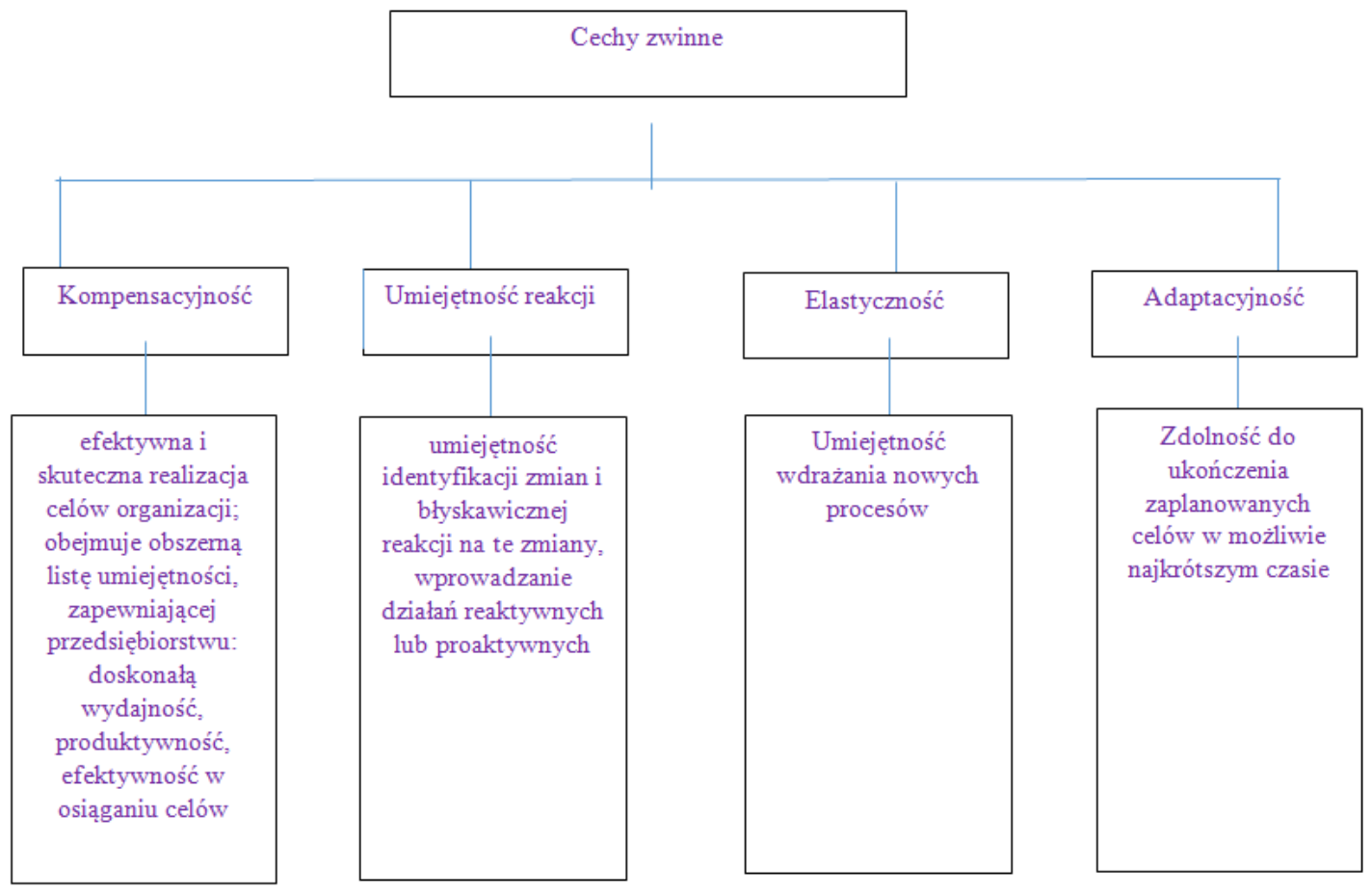

Rysunek 2: Klasyfikacja cech zwinnych

Źródło: Sharifi, Zhang, 1999, s. 7-22.

Każda organizacja, w tym również innowacyjna, funkcjonuje w warunkach ryzyka, które stanowi jedno z podstawowych zjawisk ekonomicznych i na które narażoną jest każdy uczestnik rynku (Pukała, 2016, s. 3-4). Przez przyjęcie ryzyka rozumieć można możliwość wystąpienia odchylenia faktycznego wyniku decyzji od wyników planowanych, zaznaczając, iż pojawia się ewentualność wystąpienia odchylenia zarówno pozytywnego, jak i negatywnego. Ryzyko pozostaje zatem nieodłączną częścią działalności prowadzonej przez przedsiębiorstwa (Chrapko, 2010, s. 215-266).

Ryzyko należy interpretować w kategorii zagrożenia nieosiągnięcia planowanych celów i oddziałuje w istotnym stopniu na pojawienie się zdarzeń wpływających negatywnie na sytuację danej firmy (Zawadzka, 1999, s. 9). Pewnym jest, iż w działalności gospodarczej nie sposób uniknąć ryzyka, z racji tego, iż w chwili podejmowania decyzji nie ma możliwości dysponowania pełną informacją. Dlatego pełna antycypacja dalszego rozwoju wydarzeń nie jest możliwa. Rozmiary ryzyka pojawiającego w działalności organizacji uzależnione pozostają od wielu wzajemnie powiązanych ze sobą czynników. Duża część z nich przyjmuje charakter zewnętrzny, niezależnie od działań firmy. Wśród nich znajdują się czynniki ogólnogospodarcze, społeczne, demograficzne, polityczne, oraz czynniki techniczne (Surdel, 2006, s. 66-67).

Przeciwdziałanie materializacji ryzyka stanowi jeden z elementów efektywności gospodarowania. Dotyczy to zwłaszcza podmiotów gospodarczych, w których poziom oszczędności oraz zakumulowany kapitał są na ogół niewystarczające do kontynuowania działalności w przypadku zaistnienia zagrożeń destabilizujących jego funkcjonowanie. Wtedy istotnego znaczenia nabiera sprawne zarządzanie ryzykiem, dążące do minimalizacji strat finansowych związanych $\mathrm{z}$ jego zaistnieniem. Efektywne zarządzanie ryzykiem w działalności przedsiębiorstwa trzeba uznać zatem za nieodzowny element działalności gospodarczej. Proces ten podlega stałym zmianom w czasie, a ponadto nakłada na kadrę zarządzającą przedsiębiorstwem szeroki wachlarz obowiązków, których celem jest ograniczanie ryzyka i optymalne zabezpieczanie firmy przed negatywnymi jego skutkami (Pukała, 2016, s. 3-4).

Ograniczanie ryzyka w działalności organizacji obejmuje takie przedsięwzięcia, które przyjmują za cel analizę sterowania ryzykiem, a także kontrolę podejmowanych przedsięwzięć. Działania te powinny przyjmować charakter planowy i celowy, nie należy ich podejmować bardziej lub mniej sporadycznie, lecz systematycznie i długofalowo. Niezbędna pozostaje również integracja takich przedsięwzięć w ramach kompleksowego systemu zarządzania organizacją. Przedsięwzięcia te obejmują następujące kwestie (Janasz, 2013, s. 149): identyfikacja ryzyka, sterowanie ryzykiem, oraz kontrola podejmowanych przedsięwzięć.

\section{CECHY ZWINNE JAKO CZYNNIK OGRANICZAJĄCY RYZYKO W DZIALALNOŚCI ORGANIZACJI}

Każda organizacja, aby osiągnąć pożądane cele, zmuszona jest podejmować ryzyko. Efektywne i zintegrowane zarządzanie ryzykiem wymaga wkomponowania go w proces zarządzania przedsiębiorstwem. Otoczenie biznesowe stwarza szanse na osiągnięcie zaplanowanych zysków, lecz pojawia się również ryzyko strat w wyniku niekorzystnych zmian na zewnątrz i wewnątrz firmy. W momencie podejmowania wszelkich decyzji nigdy nie można mieć pewności co do tego jak ukształtują się warunki realizacji planowanego przedsięwzięcia. W warunkach występowania ryzyka przedsiębiorstwa zmuszone są poszukiwać sposobów jego minimalizacji. Doniosłą rolę w procesie zarzadzania ryzykiem pełnią pracownicy. Ich postawa decyduje w dużej mierze o skutecznym eliminowaniu ryzyka. Sukces w tej materii 
zależy od cech pracowników, które można określić jako zwinne. Zwinne atrybuty wykorzystywane są na każdym z etapów zarządzania ryzykiem.

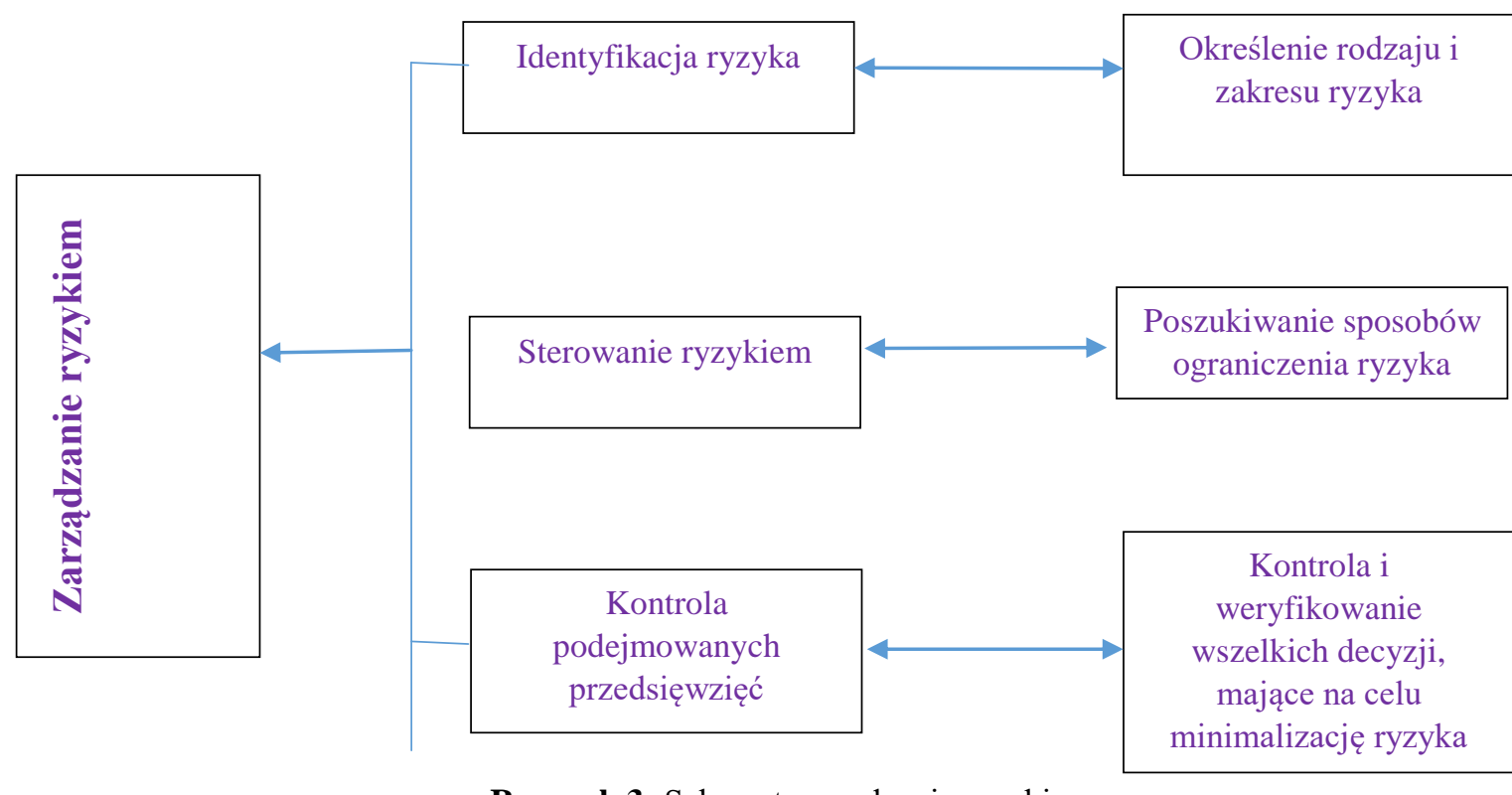

Rysunek 3: Schemat zarządzania ryzykiem

Źródło: Opracowanie własne

Identyfikację ryzyka umożliwia wykształcenie się zachowań proaktywnych u pracownika. Proaktywność oznacza umiejętność błyskawicznej reakcji na różnorakie bodźce, pochodzące zarówno z wnętrza organizacji oraz na sygnały $\mathrm{z}$ otoczenia rynkowego i zarazem zdolność do podejmowania niestandardowych rozwiązań. Cecha ta pozwala na błyskawiczną identyfikację ryzyka (Zawadzka, 2001, s. 9). Identyfikacja ryzyka przyjmuje charakter informacyjny i prognostyczny. Głównym punktem wyjścia do analizy ryzyka pozostaje niewątpliwie jego identyfikacja, oznaczająca określenie, jakimi rodzajami ryzyka oraz w jakim zakresie jest $\mathrm{w}$ danym momencie zagrożone przedsiębiorstwo. Czynność ta wymaga dogłębnej analizy poszczególnych transakcji, biorąc pod uwagę zagrożenie ich ryzykiem, a następnie ich klasyfikacje.

Działanie pracownika proaktywnego oparte jest na prawie akcji i reakcji. Podczas pojawienia się ryzyka, pracownik potrafi je sprawnie zidentyfikować, zachowując przy tym spokój i trzeźwość myślenia w trudnych okolicznościach (Gunasekaran, 1999, s. 180-187; Ofoegbu, Akanbi, 2012, s. 1-12). Potrafi dokładnie przeanalizować poszczególne zdarzenia gospodarcze z punktu widzenia zagrożenia ich ryzykiem oraz sprawnie dokonać ich klasyfikacji oraz kwantyfikacji, czyli pomiaru ryzyka za pomocą różnych metod. W pracy charakteryzuje go umiejętność rozwiązywania nowych i złożonych problemów oraz przyjmowania niestandardowych działań, w sytuacji, kiedy zaistnieje nagły problem (Olesiński i in., 2017, s. 75-81).

Proaktywny pracownik potrafi skutecznie sterować ryzykiem. Jego atrybutem jest poszukiwanie nowych, innowacyjnych sposobów ograniczania ryzyka (Olesiński i in. 2017, s. 75-81). Schemat wyszczególniający rolę cech proaktywnych w zarządzaniu ryzykiem przedstawia rys. 4. Ponadto, zwinne zachowania pracownika pojmuje się w kategorii ich adaptacyjności. Postawa taka rozumiana jest jako ,proces świadomej i podświadomej modyfikacji społecznej nabytych cech, tak aby były one zgodne ze wzorcem cech uznawanych w danym środowisku za normalne $\mathrm{i}$ pożądane i aby pozwalały na rozwiązanie problemów współżycia w sposób możliwie bezkonfliktowy" (ŻarczyńskaDobiesz, 2008, s. 35-36).

Zachowania adaptacyjne w dużym stopniu umożliwiają prawidłowe sterowanie ryzykiem. Podczas zarządzania ryzykiem cechy adaptacyjne pozwalają na podejmowanie w pracy wielu ról, pełnienia wielozadaniowości i działań na wielu poziomach organizacji. Aby ograniczyć ryzyko niepowodzeń określonego projektu, pracownik musi przejść bardzo szybko z jednej roli do drugiej. Pracownicy posiadający moc wytwórczą muszą nauczyć się jednocześnie działać w wielu dziedzinach, wykorzystywać kompetencje i uczyć się poprzez aktywne udostępnianie informacji i wiedzy (Dyer, Shafer, 2003, s. 145-174).

W ramach sterowania ryzykiem pracownicy o cechach adaptacyjnych potrafią podejmować następujące rodzaje działań (Zawadzka, 2001, s. 9): 1) unikać ryzyka, poprzez nie angażowanie się w transakcje o dużym prawdopodobieństwie niepowodzenia, 2) dokonywać dywersyfikacji ryzyka, oraz 3) opracowywać plany awaryjne dla ryzyka najbardziej prawdopodobnego, pojawiającego się, pomimo podjęcia działań na rzecz jego minimalizacji. Schemat adaptacyjnego zachowania pracownika w obliczu wystąpienia ryzyka pokazano na rys. 5. Zwinne zachowania można pojmować także w kategorii prężności, rozumianej jako funkcjonowanie pod naciskiem, pomimo nieustannie zmieniających się warunków pracy, jak również w sytuacji, kiedy stosowane strategie i rozwiązania okazują się niewystarczające (Dyer, 
Shafer 2003, s. 145-174). Prężność w obliczu ryzyka oznacza umiejętność radzenia z nim sobie, oraz z związanymi z nimi nieoczekiwanymi sytuacjami i ze stresem.

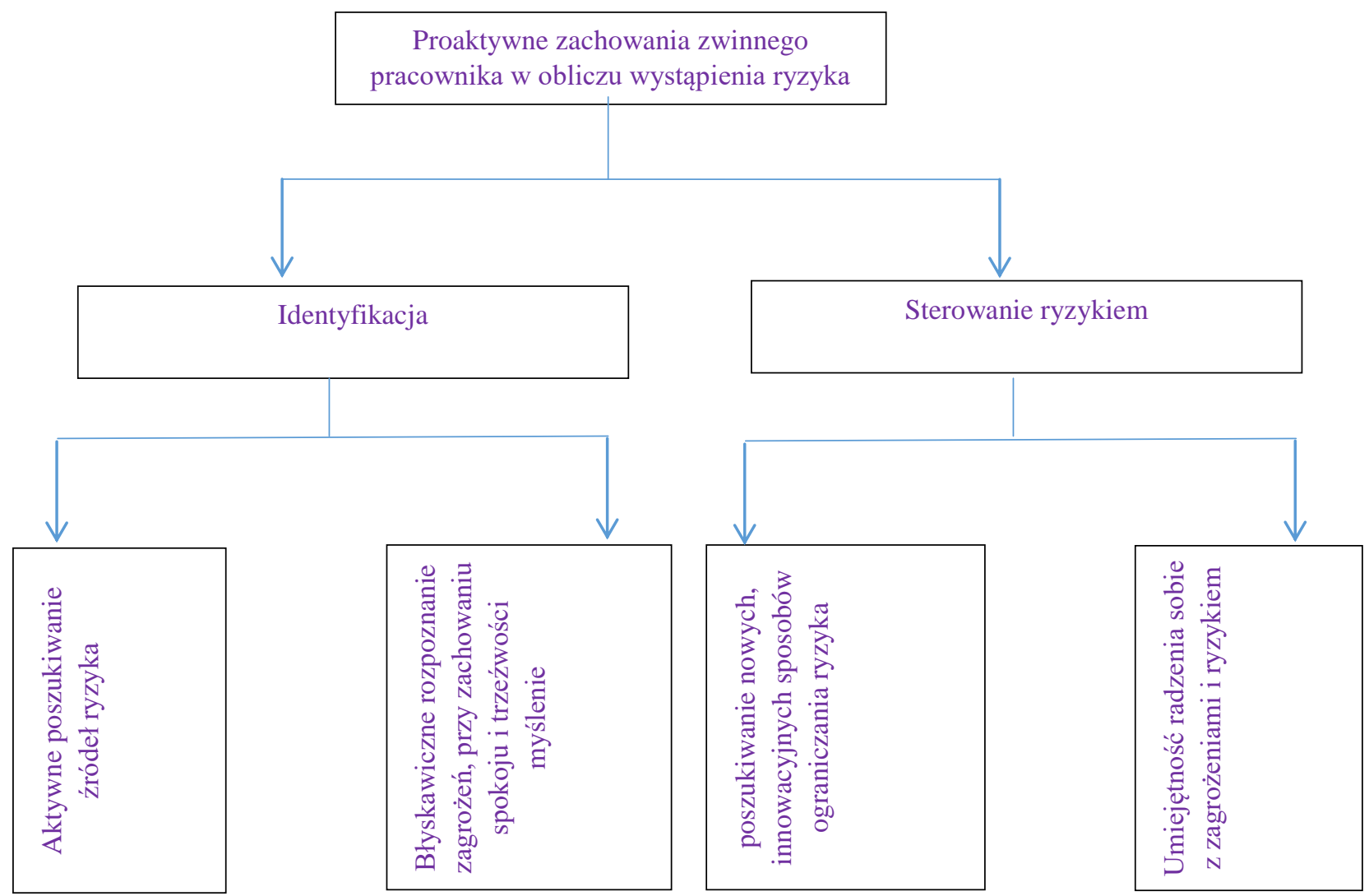

Rysunek 4: Proaktywne zachowania zwinnego pracownika w obliczu wystąpienia ryzyka

Źródło: Opracowanie własne

W literaturze przedmiotu występują dwa terminy związane z problemem prężności: resilence i resilency. Prężność można określać dwojako: jako proces oraz jako cechy osobowości. Wedle pierwszej interpretacji ,prężność odnosi się do procesu dynamicznej i pozytywnej adaptacji w obliczu przejawiających się przeciwności” (Luthar, 2012, s. 429-449). „Jest konstruktem wymiarowym, obejmującym istotne czynniki powiązane ze skuteczną adaptacją do stresujących wydarzeń" (Charney, 2004, s. 195). Zatem termin „resilence” można pojmować jako efektywne radzenie sobie z negatywnymi wydarzeniami i zjawiskami, w tym z ryzykiem. Drugi termin oznacza z kolei właściwości osobowości danego pracownika. Potocznie takie zachowanie zwykło określać się elastycznym lub giętkim. Jest ono niezwykle przydatne w sterowaniu ryzykiem (Żarczyńska-Dobiesz, 2008, s. 35-36).

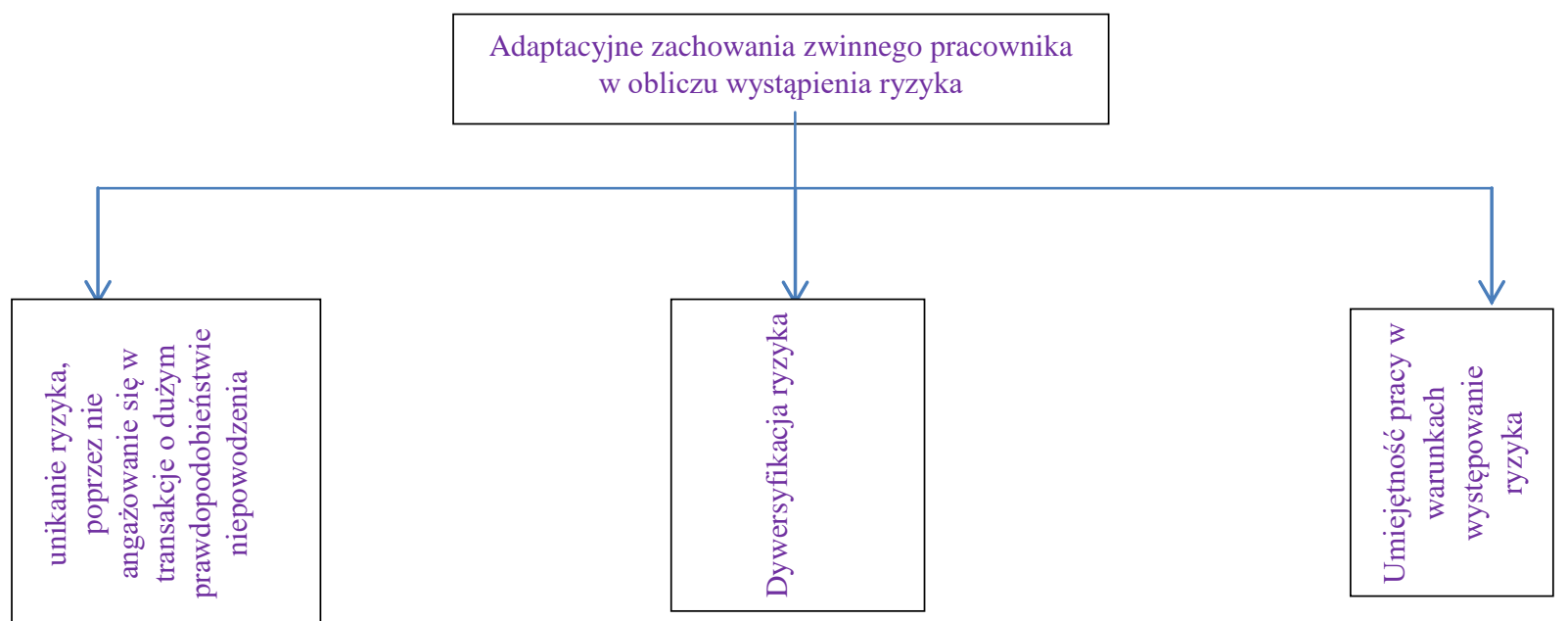

Rysunek 5: Adaptacyjne zachowanie zwinnego pracownika

Źródło: Opracowanie własne 
Prężność pojmować można więc w kategorii dynamicznego procesu, w którym jednostka jest narażona na trudną sytuację, jaką pozostaje funkcjonowanie w obliczu ryzyka. Wykazuje przy tym oznaki pozytywnej adaptacji do tej sytuacji, przejawiające się we wzroście kompetencji, realizacji zadań rozwijających i niewystępowaniu zaburzeń emocjonalnych bądź zachowania (Ostaszewski, 2005, s. 1-5). Prężność traktowana może być też w kategorii cech osobowości, które pozostają kluczowe w procesie zmagania się z problemami, jakie występują podczas świadczenia pracy. Do takich problemów należy m.in. działalność w obliczu ryzyka. Zatem prężność pojmowana jest jako podstawowa właściwość osobowościowych procesów regulacyjnych, wskazująca na funkcjonowanie specyficznego układu właściwości charakterologicznych (Goriwondo i in., 2013, s. 1-11). Prężna postawa pracownika, przyczyniając się do odczuwania przez pracownika satysfakcji $\mathrm{z}$ wykonywanej pracy, koreluje $\mathrm{z}$ takimi psychologicznymi konstruktami jak samoocena, optymizm, wewnętrzne poczucie kontroli czy poczucie własnej skuteczności i własnej wartości (Bagozzi, Youjae, 2012, s. 40-44). Postawa ta wiąże się z takimi jego cechami jak pewność siebie, umiejętność zjednania akceptacji innych pracowników, dążenie do celu, umiejętność pracy w sytuacjach stresowych, wewnętrzny spokój i opanowanie oraz poczucie własnej skuteczności, nawet w sytuacjach bardzo trudnych (Ogińska-Bulik, Juczyński, 2010, s. 24-32). Prężny pracownik jest zatem w stanie odpowiednio wykonywać swoje obowiązki w trudnych albo stresujących sytuacjach, do których należy funkcjonowanie w obliczu ryzyka (Prince-Embury, 2008, s. 41-56).

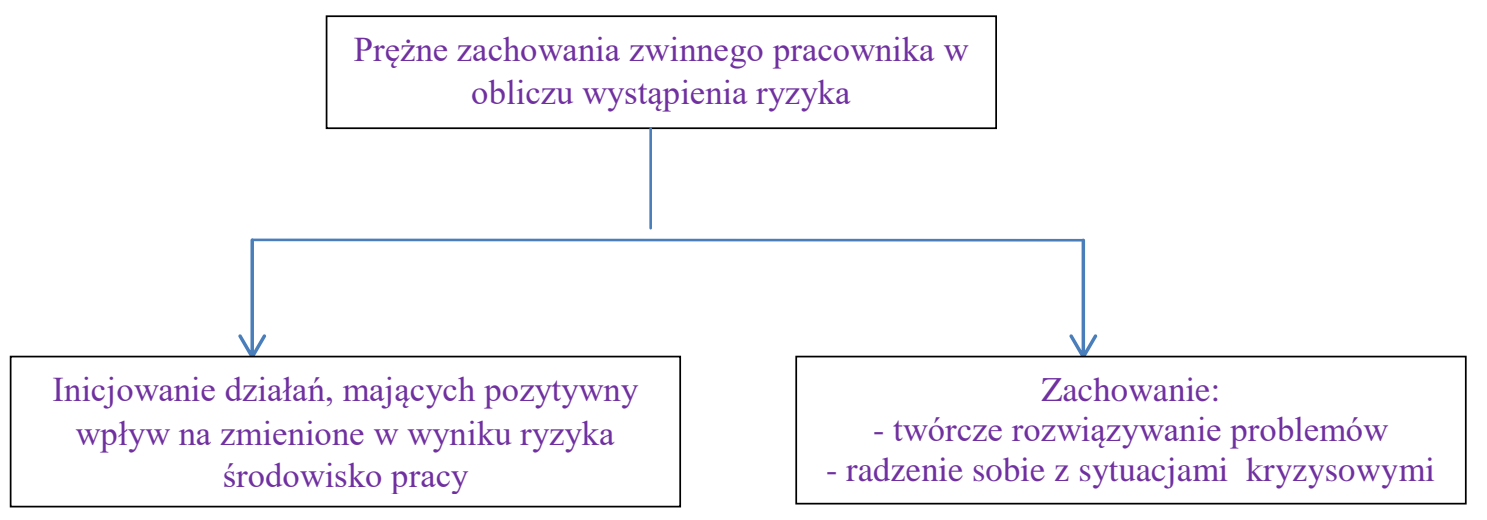

Rysunek 6: Prężne zachowania zwinnego pracownika w obliczu wystąpienia ryzyka

Źródło: Opracowanie własne

Minimalizacja zagrożeń, a tym samym ograniczenie ryzyka, wymaga nie tylko określonych środków finansowych, materialnych czy nakładów pracy, lecz przede wszystkim kadry obdarzonej dużą wiedzą i stałym dopływem wartościowych informacji. Zwinny pracownik obdarzonym cechami prężnymi jest w stanie na bieżąco poszerzać swoja wiedzę. Szybko zdobywa też informacje pozwalające zminimalizować ryzyko, dzięki czemu skutecznie ogranicza obszar niepewności, dotyczący przyszłych zdarzeń, a tym samym ogranicza stopień ryzyka (Ogińska-Bulik, Juczyński, 2010, s. 24-32).

Przedstawione rozważania pozwalają na przedstawienie zwinnych zachowań pracowników w obliczu pojawienie się ryzyka organizacyjnego. Niniejsze zachowania przedstawiono za pomocą teoretycznego modelu (rys. 7). Wskazano, że pojawienie się różnych rodzajów ryzyka, stanowi impuls do kształcenia zwinnych zachowań, które przyczyniają się w dużym stopniu do ograniczenia tego ryzyka. Zaproponowany model oparty jest na koncepcjach Griffin'a i Hesketha'a (2003, s. 65-73), który rozszerzony został o zestawienie cech zwinnych, jako odpowiedzi na pojawiające się ryzyko. Na podkreślenie zasługuje fakt uniwersalności zaprezentowanego modelu, który przedstawia zwinne cechy przydatne w zarządzaniu ryzykiem organizacyjnym, na przykład diagnozy występowania ryzyka i wykształcających się w odpowiedzi na ryzyko cech zwinności.

\section{WNIOSKI}

W artykule wskazano, iż jedną z możliwych reakcji współczesnych przedsiębiorstw na pojawienie się ryzyka organizacyjnego jest promowanie zwinności pracowniczej. Zwinny pracownik potrafi skutecznie przewidywać problemy występujące $\mathrm{W}$ związku z pojawieniem się ryzyka, posiada umiejętność rozwiązywania problemów związanych z wystąpieniem ryzyka. W takich sytuacjach potrafi wdrożyć innowacyjne pomysły oraz efektywnie wykonywać swe obowiązki w stresujących warunkach, a także zaproponować nowe procedury lub procesy dla swojego obszaru pracy. Napawa to optymizmem, ponieważ nabycie cech zwinności w obliczu ryzyka organizacyjnego powinno pomóc w zarządzaniu nim i potencjalnie zapewnić wzrostu konkurencyjności organizacji. 


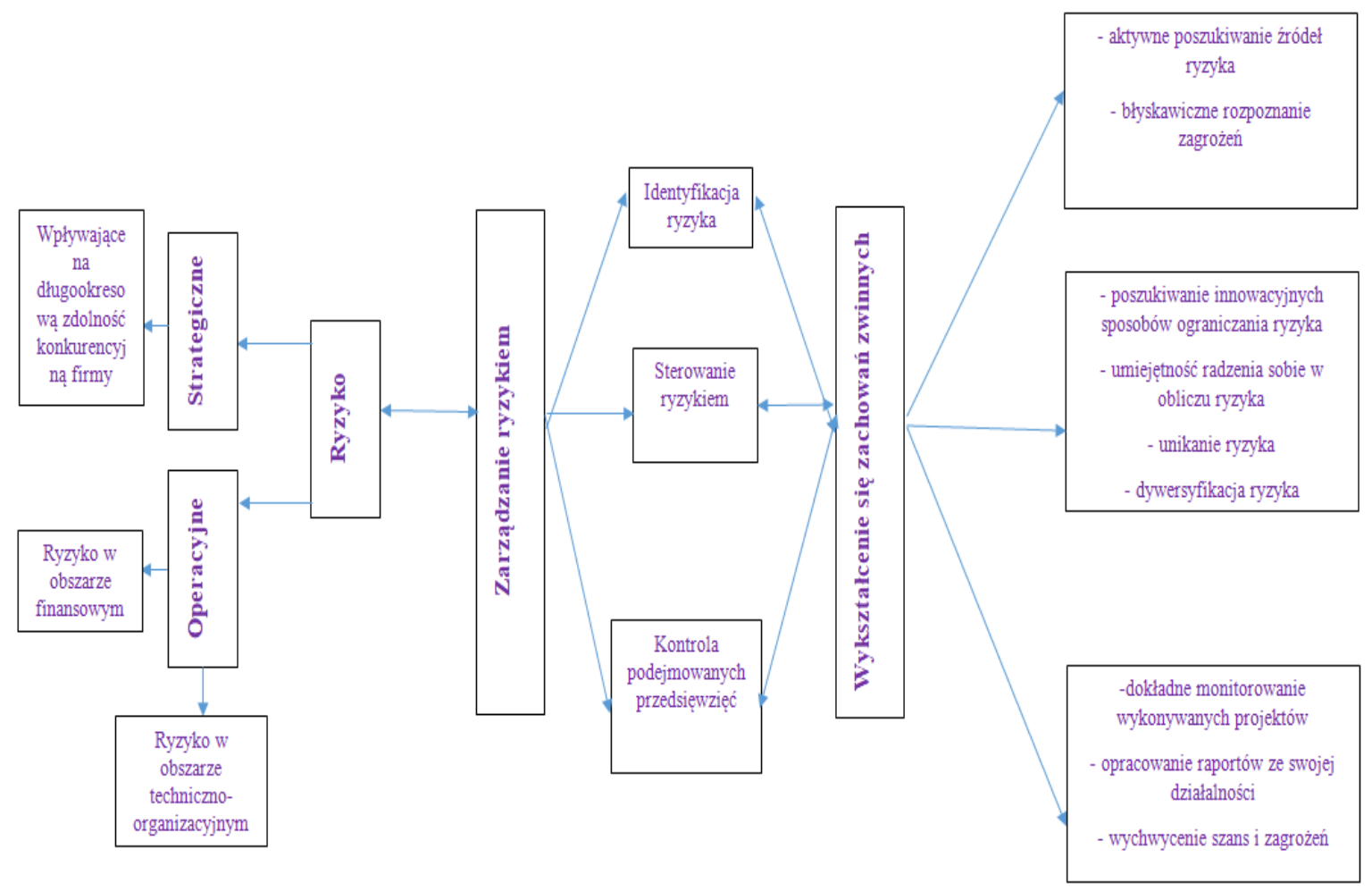

Rysunek 7: Zachowania zwinnych pracowników w obliczu pojawienia się ryzyka organizacyjnego

Źródło: Opracowanie własne

\section{Bibliografia}

1. Bagozzi, R., Youjae, Y. (2012). Specification, evaluation, and interpretation of structural equation models, Journal of the Academy of Marketing Science, 40, 8-34. https://doi.org/10.1007/s11747-011-0278-x

2. Bełz, G., Barbasz, A. (red.) (2004). Research Papers. Management Forum 4, Wrocław: Wyd. Uniwersytetu Ekonomicznego.

3. Bessant, J. i in. (1999). Developing manufacturing agility in SME's. International Journal of Technology Management, 5.

4. Breu, R. i in. (2002). Model Driven Security for Inter - Organizational Workflows in E-Government, In Proc. TCGOV, ISCA.

5. Charney, D.S. (2004). Psychobiological mechanisms of resilience and vulnerability: implications for successful adaptation to extreme stress, American Journal of Psychiatry, 161(2), 195-216. https://doi.org/10.1176/a ppi.ajp.161.2.195

6. Chrapko, M. (2010). CMMI - Doskonalenie procesów w organizacji, Warszawa: Wyd. Naukowe PWN.

7. D'Aveni, R. A. (1994). Hypercompetition: Managing the Dynamics of Strategic Maneuvering, The Free Press: New York.

8. Doz, Y., Kosonen, M. (2008). The Dynamics of Strategic Agility: Nokia's Rollercoaster Experience, California Management Review, 50(3), 95-118. https://doi.org/10.2307/41166447

9. Dyer, L., Shafer, R.A. (2003), Dynamic organizations: Achieving marketplace and organizational agility with people. Ithaca, New York: Cornell University, School of Industrial and Labor Relations, Center for Advanced Human Resource Studies.

10. Goldman, S.L. i in. (1995). Agile Competitors and Virtual Organizations: Strategies for Enriching the Customer, New York: Van Nostrand Reinhold.

11. Griffin, B., Hesketh, B. (2003). Adaptable behaviours for successful work and career adjustment, Australian Journal of Psychology, 55(2), 66-73. https://doi.org/10.1080/00049530412331312914

12. Goriwondo, W. M. (2013). Agility for sustainability in Zimbabwe: A case study for manufacturing companies in Bulawayo, China - USA Business Review, 12(1), 38-51. https://doi.org/10.17265/1537-1514/2013.01.005

13. Gunasekaran, A., (1998). Agile manufacturing: enablers and an implementation framework. International Journal of Production Research, 36(5), 1223-1247. https://doi.org/10.1080/00 2075498193291

14. Gunasekaran, A. (1999). Organisational quality - a cognitive approach to quality management, The TQM Magazine, 11, 180-187. https://doi.org/10.1108/09544789910262752

15. Herzenberg, S.A. i in. (1998). New Rules for a New Economy: Employment and Opportunity in Postindustrial America, Ithaca, New York: ILR Press/Cornell University Press.

16. Hopp, W.J. i in. (2004). Benefits of skill chaining in production lines with cross-trained workers, Management Science, 50(1), 83-98. https://doi.org/10.1287/mnsc.1030.0166 
17. Hormozi, A.M. (2009). Agile manufacturing: the next logical step, Benchmarking, 8. https://doi.org/10.1 $\underline{108 / 14635770110389843}$

18. Janasz, K., Wiśniewska, J. (2013). Innowacje i jakość w zarządzaniu organizacjami, Warszawa: CeDeWu.

19. Kidd, P.T. (1994). Agile Manufacturing: Forging New Frontiers, Reading, MA: Addison-Wesley.

20. Liao, H., Subramony, M. (2008). Employee Customer Orientation in Manufacturing Organizations: Join Influences of Customer Proximity and the Senior Leadership Teams. Journal of Applied Psychology, 93(2), 317-328. https://doi.org/10.1037/0021-9010.93.2.317

21. Luthar, S. (2012). Are affluent youth truly "at risk"? Vulnerability and resilience across three diverse samples, Development and Psychopathology, 24(2), 429-49. https://doi.org/10.1017/S095 4579412000089

22. Meredith, S., Francis, D. (2000). Journey towards agility: The agile wheel explored, The TQM Magazine, 12(2), 1-11. https://doi.org/10.1108/09544780010318398

23. Narasimhan, R. i in. (2006). Multiproduct, multicriteria model for supplier selection with product life-cycle considerations, Decision Sciences, 37, 577-603. https://doi.org/10.1111/j.1540-5414.2006.00139.x

24. Ofoegbu, O.E., Akanbi, P.A. (2012). The influence of strategic agility on the perceived performance of manufacturing firms in Nigeria, International Business \& Economics Research Journal, 11(2), 153-160. https://doi.org/10.19030/iber.v11i2.6769

25. Ogińska-Bulik, N., Juczyński, Z. (2010), Osobowość, stres a zdrowie, Warszawa: Difin.

26. Olesiński, A. i in. (2017). Zarządzanie międyzorganizacyjne w zwinnych przedsiębiorstwach. Warszawa: Texter.

27. Ostaszewski, K. (2005). Druga strona ryzyka, Warszawa: Remedium.

28. Plonka, F. E. (1997). Developing a lean and agile work force, Human Factors and Ergonomics in Manufacturing \& Service Industries, 7(1), 11-20. https://doi.org/10.1002/(SICI)15206564(199724)7:1<11::AID-HFM2>3.0.CO;2-J

29. Prince-Embury, S. (2008). The resiliency scales for children and adolescents, psychological symptoms, and clinical status in adolescents, Canadian Journal of School Psychology, 23(1), 41-56. https://doi.org/10. $1177 / 0829573508316592$

30. Pukała, R. (2016). Use of neural networks in risk assessment and optimization of insurance cover in innovative enterprises. Economics and Management, 8(3), 43-56. https://doi.org/10.1515/emj-2016-0023

31. Rigby, K. (2000). Bullying in schools: guidelines to effective action, Professional Reading Guide for Educational Administrators, 21, 31-37.

32. Sajdak. M.K. (2013). Zwinność jako źródło przewagi konkurencyjnej i sukcesu przedsiębiorstwa, Gdańsk: Wyd. Wydziału Zarządzania Uniwersytetu Gdańskiego.

33. Sanchez, L.M., Nagi, R. (2001). A review of agile manufacturing systems, International Journal Production Research, 39(16), 3561-3600. https://doi.org/10.1080/00207540110068790

34. Sharifi, H., Zhang, Z. (1999). Methodology for achieving agility in manufacturing organization: An introduction, International Journal of Production Economics, 62, 7-22. https://doi.org/10.1016/S09255273(98)00217-5

35. Sherehiy, B. i in. (2007). A Review of Enterprise Agility: Concepts, Frameworks and Attributes. International Journal of Industrial Ergonomics, 37(5), 445-460. https://doi.org/10.1016/j.erg on.2007.01.007

36. Storey, J. i in. (2005). The barriers to customer responsive supply chain management. International Journal of Operations \& Production Management, 25(3), 2-11. https://doi.org/10.1108/0144 3570510581853

37. Surdel, P. (2006). Strategie oraz systemy transakcyjne, Poznań: Złote Myśli.

38. Trzcieliński, S. (2007). Agile Enterprise. Concepts and Some Results of Research. Poznań University of Technology/IEA Press: Poznań.

39. Upton, D. M. (1995). Flexibility as Process Mobility: The Management of Plant Capabilities for Quick Response Manufacturing, Journal of Operations Management, 12(3-4), 205-224. https://doi.org/10.1 016/02726963(95)00004-C

40. Van Oyen, M. P. i in. (2001). Performance opportunity for workforce agility in collaborative and noncollaborative work systems. IIE Transactions, 33, 761-777. https://doi.org/10.1080/ 07408170108936871

41. Youndt, M.A. i in. (1996). Human Resource Management, Manufacturing Strategy, and Firm Performance. Academy of Management Journal, 39(4), 836-866. https://doi.org/10.5465/256714

42. Zawadzka, Z. (2001). Ryzyko bankowe, Warszawa: Awim Mediabank S.A.

43. Zawadzka, Z. (1999). Zarzadzanie ryzykiem w banku komercyjnym, Warszawa:Poltex.

44. Zhang, Z., Sharifi, H. (2000). A methodology for achieving agility in manufacturing organizations. International Journal of Operations \& Production Management, 20(4), 10-21. https://doi.org/10.1 $108 / 01443570010314818$

45. Żarczyńska-Dobiesz, A. (2008). Adaptacja nowego pracownika do pracy w przedsiębiorstwie, Warszawa: Wyd. Wolters Kluwer. 